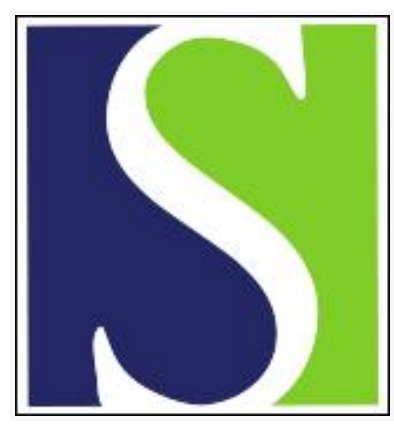

Scand J Work Environ Health 1980;6(3):197-200

https://doi.org/10.5271/sjweh.2616

Issue date: Sep 1980

A retrospective cohort study of mortality among stainless steel welders.

by Sjögren B

Key terms: cohort study; mortality; pulmonary tumor; retrospective cohort study; retrospective study; stainless steel; stainless steel welder; welder; welding

This article in PubMed: www.ncbi.nlm.nih.gov/pubmed/6937824

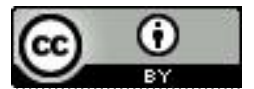




\title{
A retrospective cohort study of mortality among stainless steel welders
}

\author{
by Bengt Sjögren, $M^{\top}{ }^{\top}$
}

\begin{abstract}
SJOGGREN B. A retrospective cohort study of mortality among stainless steel welders. Scand $j$ work environ health 6 (1980) 197-200. Hexavalent chromium particles are generated in the welding of stainless steel. These particles have manifested a mutagenic action in bacterial test systems and produced chromosome aberrations in cultured Chinese hamster cells. Welders who had welded stainless steel for more than 5 a during 1950-1965 were selected for this study. According to an earlier survey the hexavalent chromium exposure of such welders was often above $50 \mu \mathrm{g} / \mathrm{m}^{3}$ (calculated as $\mathrm{CrO}_{3}$ ). The cohort was followed until December 1977. The expected number of deaths was calculated from cause-, gender-, age-, and year-specific death rates of the general population in Sweden. In the cohort, consisting of 234 welders, the observed numbers of total deaths and deaths caused by tumors were the same as the expected numbers. However, three welders had died from pulmonary tumors in comparison to the expected number of $0.68(\mathrm{p}=0.03)$.
\end{abstract}

Key terms: pulmonary tumors, welding.

Stainless steel is usually welded by one of two electric-arc methods, one using covered electrodes and the other shielding gas. In both these methods an electric voltage creates an arc between the electrode and the welded material. The covered electrodes produce gases and slag which protect the splice against the oxidational power of the air. This method is also called manual metal arc welding. In gas-shielded welding an inert gas, argon, protects the splice against the air. This method is further subdivided into metal inert-gas (MIG) welding, using a consumable electrode, and tungsten inert-gas (TIG) welding, using a nonconsumable electrode.

A survey of welders working with stainless steel in Sweden was performed in 1974

1 Department of Occupational Medicine, National Board of Occupational Safety and Health, Solna, Sweden.

Reprint requests to: Dr Bengt Sjögren, Department of Occupational Medicine, National Board of Occupational Safety and Health, S-171 84 Solna, Sweden.
(4). About 400 persons carried out welding with covered electrodes, and about 500 persons carried out gas-shielded welding for more than $50 \%$ of their worktime.

Stainless steel is an alloy which contains mainly iron but also chromium (10-20\%) and nickel $(0.5-20 \%)$. The electrodes used contain about the same amount of chromium and nickel. The chromium in airborne particles is mainly in the soluble hexavalent form when covered electrodes are used for welding. Gas-shielded welding produces much less hexavalent chromium $(10,19,20,21,22)$.

Bacteria tests have shown fumes from covered-electrode stainless steel welding to be more mutagenic than fumes from gasshielded welding. Fumes from mild steel welding have no mutagenic effect $(5,11)$. Fume particles from stainless steel have also been shown to produce sister chromatid exchanges and chromosome aberrations in cultured Chinese hamster cells. In this case too, covered-electrode welding produced more cytogenetic changes than did gas-shielded welding (9). Some epidemiologic studies have shown welding in 
general not to be associated with an increased risk of tumor development (2, $6,25)$.

The purpose of this study was to investigate mortality and the incidence of tumors in a group of welders exposed to stainless steel welding fumes.

\section{Material and methods}

Eight different companies, from Lund in the south to Avesta in the north of Sweden, provided lists of welders. Welders who had stainless steel welding as their main task for at least 5 a sometime between 1950 and 1965 were selected for the cohort. Name, ten-digit identification number based on date of birth, and the most used welding method were registered for all the welders. In some workshops, asbestos had been used earlier for heat insulation. Welders were included in the cohort only if representatives from the companies stated that asbestos had not been used or had been used very occasionally and never in a dust-generating way. Measurements of airborne asbestos had never been performed in any of the companies.

The selected cohort consisted of 234 welders, all males. Most of them had welded with covered electrodes. Gasshielded welding, most frequently TIG, was performed by only a small number of welders. The eventual mortality of the welders was traced through the registration books of their local parishes until December 1977. All of the cohort could be identified in these registers. All death certificates were checked against the classification made by the Swedish National Central Bureau of Statistics (SNCBS). The expected numbers of deaths were calcu- lated by the multiplication of the personyears of observation within 5-a age categories during 1955-1977 by cause-, gender-, age-, and year-specific national death rates, given by the SNCBS. The participants in the cohort were checked in the National Cancer Register for the occurrence of cancer. Person-years at risk were calculated after the minimum 5-a exposure time. The calculations of the p-values were based on the Poisson distribution (3).

\section{Exposure}

Air pollution in stainless steel welding was surveyed in Sweden in 1975 (21). The median time-weighted-average value for chromium was $210 \mu \mathrm{g} / \mathrm{m}^{3}$, and the highest concentration was $1,440 \mu \mathrm{g} / \mathrm{m}^{3}$, which was found in the welding involving covered electrodes. Eighty-five percent of the 85 chromium measurements exceeded $50 \mu \mathrm{g} / \mathrm{m}^{3}$, which was the threshold limit value (TLV) for chromium trioxide in Sweden in 1975. In gas-shielded welding the median chromium concentration was $20 \mu \mathrm{g} / \mathrm{m}^{3}$, and the highest concentration $840 \mu \mathrm{g} / \mathrm{m}^{3}$. The majority of these measurements were made when workers were performing TIG welding. About one-third of the 41 chromium measurements exceeded the TLV. However, this is an overestimation of the hexavalent chromium exposure since only a minor fraction was in the hexavalent form.

Measurements of stainless steel welding fumes do not exist for the period 19501965. Representatives from the eight companies from which the cohort was selected had the impression that particle exposure was similar to that of 1975 . In some workshops the welding fume exposure was assumed to be somewhat higher 25 a ago.

Table 1. Expected and observed number of deaths from different causes among 234 stainless steel welders contributing 3,735 person-years.

\begin{tabular}{lccc}
\hline Cause of death & Expected & Observed & Ratio \\
\hline All & 17.75 & 17 & 1.0 \\
Cardiovascular & 4.99 & 6 & 1.2 \\
Tumors & 4.01 & 4 & 1.0 \\
Pulmonary tumors & 0.68 & 3 & 4.4 \\
\hline
\end{tabular}




\section{Results}

In the total cohort, consisting of 234 welders, the observed number of total deaths and the observed number of deaths caused by tumors are the same as the expected numbers (table 1). Three welders died from pulmonary tumors, whereas the expected number was $0.68(p=0.03)$. However, only one person died from a tumor of other origin than the lung, compared to the expected number 3.33 (4.01 minus 0.68 ), which corresponds to $p=0.15$. Most welders, 207 out of 234, had been occupied mainly with covered-electrode stainless steel welding.

All three of the welders who died from pulmonary tumors had histologically different types of tumors. Welder A welded with covered electrodes on stainless steel from mid-1940 on and died in 1957 at the age of 59 from a squamous cell carcinoma. Welder B had welded with covered electrodes from the middle of 1940 until 1957. He died at 65 a of age in 1977 of a nondifferentiated pulmonary tumor. Welder $\mathrm{C}$ had worked with gas-shielded welding from the beginning of 1940 until 1969. He died in 1977 because of a highly differentiated adenocarcinoma. He was 75 a old. Welder A and B had smoked and welder C had stopped smoking 20 a before his death.

One welder died from a cecal carcinoma.

In the National Cancer Register another welder was found with a malignant salivary gland tumor.

\section{Discussion}

The total number of observed tumors was the same as the expected number. The observed number of pulmonary tumors was higher than expected. This finding could be due to chance but the probability of observing three pulmonary tumors against an expected 0.68 by chance is equal to or less than 0.03 .

Workers exposed to easily soluble hexavalent chromium in the chromium plating industry showed a higher frequency of tumors (14) or a higher frequency of pulmonary tumors than would have been expected (23). The Nordic Expert Group on Documentation of Occupational Exposure Limits suggests that both chromates and chromic acid should be regarded as carcinogens (12).

The frequency of smokers varies between 37 and $56 \%$ in different groups of welders in Sweden $(13,15,16,17)$. In different studies of the male population in Sweden the percentage of smokers has varied between 46 and $54(8,18,24)$. Therefore there is no reason to assume an important difference between this cohort of welders and the total Swedish male population. If this cohort should contain $10 \%$ more smokers than the reference population, the expected number of deaths due to pulmonary carcinoma would be underestimated. This underestimation has been calculated to be about $1 / 1.22$ (1). If this factor is compensated for, the $p$-value becomes $\mathbf{0 . 0 5}$.

According to the information given by representatives from the different companies, it seems reasonable to assume that asbestos exposure was very low in the selected cohort. - Pleural plaques discovered in a radiographic examination are an indicator of previous asbestos exposure. In a cross-sectional study of stainless steel welders none of 37 men above the age of 40 had pleural plaques (17). In Uppsala County $1.3 \%$ of the male population in the same age category had pleural plaques (7). These data indicate that the stainless steel welders had not been excessively exposed to asbestos.

Considering the results of the mutagenic tests on welding fumes and the epidemiologic studies on workers exposed to chromic acid, it seems reasonable to assume that the excess number of pulmonary tumors in this cohort could have a causal connection with the inhalation of hexavalent chromium generated in stainless steel welding. Studies on larger samples will be needed in the future to verify or refute this assumption.

\section{Acknowledgments}

This study has been supported by the Swedish Work Environment Fund, grant no $74 / 55$.

I wish to thank Ms A Thomassen for scrutinizing the Swedish Cancer Register, Mr M Bergström for making a computer 
program, Mr L Hedström and Mr I Lundberg for critical comments and Ms P Boston for editing the English.

\section{References}

1. Axelson $O$. Aspects on confounding in occupational health epidemiology, letter to the editor. Scand $\mathrm{j}$ work environ health 4 (1978) 85-89.

2. Challen PJR. Some news on welding and welders. J soc occup med 24 (1974) 38-47.

3. Cutler SJ, Schneiderman MA, Greenhouse SW. Some statistical considerations in the study of cancer in industry. Am $j$ public health 44 (1954) 1159-1166.

4. Hallne U, Erlandsson A. Arbetsmiljöproblem vid svetsning; 3 . Förekomst av svetsning $\mathrm{i}$ aluminium och rostfritt stål samt lödning med silverlod inom svensk tillverkningsindustri. Arbetarskyddsstyrelsen, Stockholm 1977 (Undersökningsrapport 1977: 6).

5. Hedenstedt A, Jenssen D, Lidesten B-M, Ramel C, Rannug U, Stern RM. Mutagenicity of fume particles from stainless steel welding. Scand $\mathrm{j}$ work environ health 3 (1977) 203-211.

6. Hedström L. Arbetsmiljöproblem vid svetsning: 10. En kohortstudie av tumörförekomst och dödlighet hos spårsvetsare IA cohort study of track welders at the Swedish State Railways concerning tumors and mortality]. Arbetarskyddsverket, Stockholm 1979, pp 41-52. (Arbete \& hälsa 1979: 28) (English summary).

7. Hillerdal G. Pleural plaques: Occurrence, exposure to asbestos, and clinical importance. Doctoral dissertation, Uppsala 1980.

8. Julin A, Wilhelmsen L. Bronchial asthma and chronic bronchitis in a random population sample. Scand j resp dis 48 (1967) $330-342$.

9. Koshi K. Effects of fume particles from stainless steel welding on sister chromatid exchanges and chromosome aberrations in cultured Chinese hamster cells. Ind health 17 (1979) 39-49.

10. Lautner GM, Carver JC, Konzen RB. Measurement of chromium VI and chromium III in stainless steel welding fumes with electron spectroscopy for chemical analysis and neutron activation analysis. Am ind hyg assoc j 39 (1978) 651-660.

11. Maxild J, Andersen M, Kiel P, Stern RM. Mutagenicity of fume particles from metal arc welding on stainless steel in the Salmonella/microsome test. Mutat res 56 (1978) 235-243.

12. Nordiska Expertgruppen för Gränsvärdesdokumentation. 8. Krom. Arbetarskyddsverket, Stockholm 1979. (Arbete \& Hälsa 1979: 33).
13. Oxhöj $\mathrm{H}$, Bake B, Wedel $\mathrm{H}$, Wilhelmsen $\mathbf{L}$. Effects of electric arc welding on ventilatory lung function. Arch environ health 34 (1979) $211-217$.

14. Royle H. Toxicity of chromic acid in the chromium plating industry. Environ res 10 (1975) $39-53$.

15. Sjögren B, Persson J, Randma E, Swensson $\AA$. Arbetsmiljöproblem vid svetsning: 9. En tvärsnittsstudie av spårsvetsare vid SJ. [A cross-sectional study of track welders at the Swedish State Railways] Arbetarskyddsverket, Stockholm 1979; pp 732 (Arbete \& hälsa 1979: 28) (English summary).

16. Sjögren B, Swensson A. Arbetsmiljöproblem vid svetsning: 4. Gasbågsvetsning i aluminium och aluminiumlegeringar. II. Medicinsk undersökning [A cross-sectional study of welders working with gas-shielded welding in aluminium and aluminium alloys] Arbetarskyddsverket, Stockholm 1978, pp 33-89. (Arbete \& hälsa 1978:6) (English summary).

17. Sjögren B, Swensson A. Arbetsmiljöproblem vid svetsning: 5. II. Medicinsk undersökning av svetsare. Metallbågsvetsning i rostfritt stål [A cross-sectional study of welders working with covered electrodes $n$ stainless steel] Arbetarskyddsverket, Stockholm 1978, pp 53-82. (Arbete \& hälsa 1978: 8) (English summary).

18. Statistiska Centralbyrån. Rökvanor i Sverige: En postenkätundersökning våren 1963 [Smoking habits in Sweden]. Stockholm 1965. (English summary).

19. Thomsen E, Stern RM. A simple analytical technique for the determination of hexavalent chromium in welding fumes and other complex matricies. The Danish Welding Institute, Glostrup 1979.

20. Tola S, Kilpiö J, Virtamo M, Haapa K. Urinary chromium as an indicator of the exposure of welders to chromium. Scand j work environ health 3 (1977) 192-202.

21. Ulfvarson U, Hallne U, Bellander T. Arbetsmiljöproblem vid svetsning: 5 . Svetsning i rostfritt stål med metallbågsvetsning och gasbågsvetsning. I. Kartläggning av luftföroreningar [Air contaminants in stainless steel welding]. Arbetarskyddsverket, Stockholm 1978, pp 1-52. (Arbete \& hälsa 1978:8) (English summary).

22. Virtamo M. Fumes from welding of stainless and acid resistent $\mathrm{Cr}-\mathrm{Ni}$-steels. Weld health VIII-635-75 (1975) 270-276.

23. Waterhouse JAH. Cancer among chromium platers. $\mathrm{Br} \mathrm{j}$ cancer 32 (1975) 262

24. Wilhelmsen L, Tibblin G. Tobacco smoking in fifty-year-old men. Scand $\mathrm{j}$ resp dis 47 (1966) $121-130$.

25. Wilhelmsen $L$, Oxhöj $H$, Bake B, Rindby A, Selin E. Investigation on effects of electric arc welding in a Swedish shipyard: A preliminary report. Bull inst marit trop med gdynia 28 (1977): $1-2,45-52$. 